\title{
Antibacterial Activities and Composition of the Essential Oils of Salvia sericeo-tomentosa Varieties
}

\author{
Nur Tan ${ }^{1 *}$, Seçil Yazıcı-Tüiüniş ${ }^{1}$, Yeter Yeşil $^{2}$, Betül Demirci ${ }^{3}$ \\ and Emir Tan ${ }^{4}$
}

\author{
${ }^{1}$ Department of Pharmacognosy, Faculty of Pharmacy, Istanbul University, 34116 Istanbul, Türkiye \\ ${ }^{2}$ Department of Pharmaceutical Botany, Faculty of Pharmacy, Istanbul University, 34116 Istanbul, Türkiye \\ ${ }^{3}$ Department of Pharmacognosy, Faculty of Pharmacy, Anadolu University, 26470 Eskisehir, Türkiye \\ ${ }^{4}$ Department of Pharmaceutical Microbiology, Faculty of Pharmacy, Istanbul Yeni Yuzyil University, \\ 34010 Istanbul, Türkiye
}

(Received December 30, 2016; Revised March 24, 2017; Accepted April 28, 2017)

\begin{abstract}
The essential oil compositions and antimicrobial activities of two varieties of a new endemic Salvia species growing in Turkey were compared. The essential oils (EOs) were obtained from the aerial parts by hydrodistillation and were analysed by gas chromatography (GC), and gas chromatography-mass spectrometry (GC-MS). The major constituents of essential oils were sabinyl acetate $(79.9-80.1 \%)$ and $\alpha$-pinene $(3.2-3.8 \%)$ in both varieties. Such high sabinyl acetate content of an essential oil of a Salvia species has not been reported hitherto. The essential oil of Salvia sericeo-tomentosa var. sericeo-tomentosa (ST) (having MIC/MBC values of $0.3 / 1.25 \mathrm{mg} / \mathrm{mL}$ ) showed better activity than the essential oil of Salvia sericeo-tomentosa var. hatayica (SH) (having MIC/MBC values of $0.6 / 1.25$ $\mathrm{mg} / \mathrm{mL}$ ) especially against Staphylococcus aureus and Bacillus subtilis. The ST and SH have exhibited significant antimicrobial activity against Escherichia coli and, methicillin-resistant S. aureus (MRSA). Whereas only modest antimicrobial activity has been observed against Pseudomonas aeruginosa, and any activity against Enterococcus faecalis, Proteus mirabilis and Klebsiella pneumoniae.
\end{abstract}

Keywords: Salvia sericeo-tomentosa var. sericeo-tomentosa; Salvia sericeo-tomentosa var. hatayica; essential oils; antibacterial activity. (C) 2017 ACG Publications. All rights reserved.

\section{Introduction}

Due to the inherent toxicities of commonly used synthetic antioxidants such as butyl hydroxyanisole (BHA) and butylate hydroxytoluene (BHT) [1, 2], many natural plant extracts and essential oils with antioxidant and antimicrobial properties have been considered as alternative food additives and systematically evaluated for the use as a food and phytopharmaceutical preservative [3-6].

\footnotetext{
* Corresponding author: E-Mail: nurtan@istanbul.edu.tr; Phone:+90 212440 0000-13413 Fax:+90 2124400252 
Salvia, with more than 900 species worldwide, is the largest genus of Lamiaceae family. Anatolia is the gene centre for Salvia in Asia [7, 8]. The genus comprises 90 species with 50\% endemism in Turkey [9]. Members of the genus known as "sage" have been traditionally used in folk medicine since ancient times. Dioscorides describes, the use of decoction of the leaves and branches of Salvia spp. is able to induce movement of the urine and the menstrual flow, is an abortifacient in his "De Materia Medica". The bioactivity studies performed on the essential oils and extracts of Salvia species show multiple pharmacological effects such as antimicrobial, antioxidative, anti-inflammatory, hypoglycemic, cardiovascular, anxiolytic, antitumor and sedative activities [10].

In this study was investigated the chemical composition and antimicrobial activity of essential oils of Salvia sericeo-tomentosa var. hatayica Celep \& Doğan (SH) and Salvia sericeo-tomentosa Rech. f. var. sericeo-tomentosa (ST) for the first time.

\section{Materials and Methods}

\subsection{The Plant Material}

The plant materials were collected from Arsuz, Hatay in May 2015. The voucher specimens have been identified and deposited in the Herbarium of the Faculty of Pharmacy, Istanbul University, Turkey (Salvia sericeo-tomentosa var. hatayica Celep \& Doğan (SH) ISTE: 107535, Salvia sericeo-tomentosa Rech. f. var. sericeo-tomentosa (ST) ISTE: 107536).

\subsection{Isolation of the Essential Oil}

The essential oils from air-dried plant materials were isolated by hydrodistillation for $3 \mathrm{~h}$, using a Clevenger-type apparatus. The obtained oils were dried over anhydrous sodium sulphate and stored at $+4^{\circ} \mathrm{C}$ in the dark and analyzed by gas chromatography (GC) and gas chromatography-mass spectrometry (GC-MS). The detailed information and chromatograms regarding GC and GC-MS were reported in the supporting information.

\subsection{Antimicrobial Activity Assay}

The antimicrobial activity of the EOs was evaluated against Gram positive and Gram negative reference standard microorganisms; S. aureus ATCC 25923, Meticillin Resistant S. aureus (MRSA) ATCC 43300, E. faecalis ATCC 29212, P. aeruginosa ATCC 27853, E. coli ATCC 25922, K. pneumoniae ATCC 4352, B. subtilis ATCC 6633, and P. mirabilis ATCC 7002 by using standard microbroth dilution method modified with rezasurin and disc diffusion method [11-13]. Experimental details of the antimicrobial activity testing were described in the supporting information.

The experiments were performed with two replications and the results were expressed as average values for the both methods (micro dilution and disc diffusion).

\section{Results and Discussion}

\subsection{Essential Oil Composition}

The essential oils were obtained by hydrodistillation from the aerial parts and were analysed by gas chromatography (GC), and gas chromatography-mass spectrometry (GC-MS).

The GC analysis of the essential oils of both species led to the identifications of 28 components, representing $98.8 \%$ for $\mathrm{SH}, 100 \%$ for ST of total oil constituents. The major constituents of oils were sabinyl acetate (79.9 - 80.1\%) and $\alpha$-pinene $(3.2-3.8 \%)$. The analysis results are given in Table 1 . 
Table 1. Chemical composition of Salvia sericeo-tomentosa var. hatayica (SH) and Salvia sericeotomentosa var. sericeo-tomentosa (ST) essential oils

\begin{tabular}{|c|c|c|c|c|}
\hline $\mathbf{R R I}^{\mathbf{a}}$ & $\mathbf{R R I}^{\mathbf{b}}$ & Compound & SH \% ${ }^{c}$ & ST \% ${ }^{\mathrm{C}}$ \\
\hline $1025^{d}$ & 1032 & $\alpha$-pinene & 3.2 & 3.8 \\
\hline $1077^{\mathrm{e}}$ & 1076 & camphene & 0.2 & 0.2 \\
\hline $1117^{\mathrm{d}}$ & 1118 & $\beta$-pinene & 0.4 & 0.7 \\
\hline $1122^{f}$ & 1132 & sabinene & 0.3 & 0.5 \\
\hline $1122^{\mathrm{f}}$ & 1135 & thuja-2,4(10)-diene & 0.3 & 0.2 \\
\hline $1160^{\mathrm{f}}$ & 1174 & myrcene & 0.1 & 0.2 \\
\hline $1212^{\mathrm{g}}$ & 1203 & limonene & $\mathrm{t}$ & 0.1 \\
\hline $1213^{\mathrm{h}}$ & 1213 & 1,8-cineole & 0.4 & 1.8 \\
\hline \multirow[t]{2}{*}{$1282^{\mathrm{e}}$} & 1280 & p-cymene & 0.8 & 0.7 \\
\hline & 1499 & $\alpha$-campholene aldehyde & $\mathrm{t}$ & $\mathrm{t}$ \\
\hline $1515^{\mathrm{f}}$ & 1532 & camphor & $\mathrm{t}$ & $\mathrm{t}$ \\
\hline $1579^{\mathrm{f}}$ & 1591 & bornyl acetate & 0.4 & $\mathrm{t}$ \\
\hline \multirow[t]{2}{*}{$1601^{\mathrm{f}}$} & 1611 & terpinen-4-ol & 0.5 & 0.4 \\
\hline & 1642 & thuj-3-en10-al & 0.2 & $\mathrm{t}$ \\
\hline $1631^{\mathrm{f}}$ & 1648 & myrtenal & 0.3 & $\mathrm{t}$ \\
\hline \multirow[t]{2}{*}{$1651^{\mathrm{f}}$} & 1651 & sabina ketone & 0.3 & $\mathrm{t}$ \\
\hline & 1658 & sabinyl acetate & 79.9 & 80.1 \\
\hline $1680^{\mathrm{f}}$ & 1683 & trans-verbenol & 0.8 & 1.2 \\
\hline $1717^{\mathrm{f}}$ & 1720 & trans-sabinol & 2.5 & 1.6 \\
\hline $1720^{\mathrm{f}}$ & 1725 & verbenone & 1.2 & 1.2 \\
\hline $1784^{\mathrm{f}}$ & 1802 & cumin aldehyde & 1.3 & 1.3 \\
\hline $1812^{f}$ & 1838 & 2-phenylethyl acetate & 0.2 & $\mathrm{t}$ \\
\hline $1836^{\mathrm{f}}$ & 1845 & trans-carveol & 0.4 & $\mathrm{t}$ \\
\hline \multirow[t]{4}{*}{$1848^{\mathrm{f}}$} & 1864 & p-cymen-8-ol & 0.5 & 0.5 \\
\hline & 1981 & cuminyl acetate & 0.5 & 0.3 \\
\hline & 2073 & p-mentha-1,4-dien-7-ol & $\mathrm{t}$ & $\mathrm{t}$ \\
\hline & 2113 & cumin alcohol & 2.5 & 3.6 \\
\hline \multirow[t]{6}{*}{$2227^{\mathrm{f}}$} & 2255 & $\alpha$-cadinol & 1.6 & 1.6 \\
\hline & & Monoterpene hydrocarbones & 5.7 & 8.2 \\
\hline & & Oxygenated monoterpenes & 91.3 & 90.2 \\
\hline & & Oxygenated sesquiterpenes & 1.6 & 1.6 \\
\hline & & Others & 0.2 & - \\
\hline & & Total & 98.8 & 100 \\
\hline
\end{tabular}

${ }^{a} \mathrm{RRI}$ indices from literature d) [13], e [14], f [15], g [16], h [17],

${ }^{\mathrm{b}}$ RRI: Relative retention indices calculated against $n$-alkanes for a polar column, $\%$ calculated from FID data, $\mathrm{t}$ Trace $(<0.1 \%)$

Numerous investigations about the chemical composition of Salvia have resulted in the isolation of various biologically active terpenoids and phenolic compounds [14-23].

In this study, the isolated major components of both Salvia sericeo-tomentosa varieties ( $\mathrm{SH}$ and ST) are sabinyl acetate (respectively 78\% and 80\%) and $\alpha$-pinene (respectively $3.2 \%$ and $3.8 \%$ ). Such high sabinyl acetate content of a Salvia essential oil has not been reported previously. In contrast, reported amount of sabinyl acetate in the volatile oils of S. lavandulifolia [24], S. yosgadensis [25], S. multicaulis var. simplicifolia [26] and S. pilifera [27] were $12.8 \%, 10.1 \%, 5.3 \%, 0.3 \%$, respectively. The varieties of the $S$. sericeo-tomentosa are belong to the section of Hymenosphace and the closely related species of them 
are S. euphratica, S. kronenburgii [28]. In the literature there are reports regarding EO compositions of these both species but without sabinyl acetat content $[29,30]$.

Sabinyl acetate is a toxic substance, its fetotoxic, abortifacient and skin irritant effects are well documented in the literature [31,32]. Due to the high sabinyl acetate content of essential oils of Salvia sericeo-tomentosa varieties, pregnant women should not use them.

\subsection{Antimicrobial Activity}

The results of MIC/MBC $(\mathrm{mg} / \mathrm{mL})$ values and disc diffusion $(\mathrm{mm})$ of Salvia sericeo-tomentosa var. hatayica (SH) and Salvia sericeo-tomentosa var. sericeo-tomentosa (ST) essential oils were summarized in Table 2.

Table 2. Microdilution method MIC/MBC* $(\mu \mathrm{g} / \mathrm{mL})$ and disc diffusion $(\mathrm{ZI}=\mathrm{mm}) *$ values results of Salvia sericeo-tomentosa var. hatayica (SH) and Salvia sericeo-tomentosa var. sericeo-tomentosa (ST) essential oils

\begin{tabular}{|c|c|c|c|c|c|c|c|c|}
\hline \multirow[t]{2}{*}{ Test strains } & \multicolumn{2}{|c|}{$\begin{array}{c}\text { S. sericeo-tomentosa } \\
\text { var. sericeo- } \\
\text { tomentosa }(\mathrm{ST})\end{array}$} & \multicolumn{2}{|c|}{$\begin{array}{l}\text { S. sericeo-tomentosa } \\
\text { var. hatayica }(\mathrm{SH})\end{array}$} & \multicolumn{2}{|c|}{ DMSO } & \multicolumn{2}{|c|}{ Ciprofloxacin } \\
\hline & $\begin{array}{c}\mathbf{Z I} \\
(\mathbf{m m})\end{array}$ & $\begin{array}{c}\mathrm{MIC} / \mathrm{MBC} \\
(\mathrm{mg} / \mathrm{mL})\end{array}$ & $\begin{array}{c}\mathbf{Z I} \\
(\mathbf{m m})\end{array}$ & $\begin{array}{c}\mathrm{MIC} / \mathrm{MBC} \\
(\mathrm{mg} / \mathrm{mL})\end{array}$ & $\begin{array}{c}\mathbf{Z I} \\
(\mathbf{m m})\end{array}$ & $\begin{array}{c}\mathrm{MIC} / \mathrm{MBC} \\
(\mathrm{mg} / \mathrm{mL})\end{array}$ & $\begin{array}{c}\text { ZI } \\
(5 \mu \mathrm{g} / \mathrm{disc} \\
\mathbf{m m})\end{array}$ & $\begin{array}{c}\mathrm{MIC} / \mathrm{MBC} \\
(\mu \mathrm{g} / \mathrm{mL})\end{array}$ \\
\hline $\begin{array}{l}\text { E.coli ATCC } \\
25922 \\
\text { S.aureus }\end{array}$ & $9 \pm 0.71$ & 1.25 & $8.5 \pm 0.35$ & 0.625 & $7 \pm 0.42$ & 6.9 & $31+2.12$ & 0.25 \\
\hline $\begin{array}{l}\text { ATCC } 25923 \\
\text { MRSA ATCC }\end{array}$ & $9 \pm 1.06$ & $0.312 / 1.25$ & $9.5 \pm 0.71$ & $0.625 / 1.25$ & $6.5 \pm 0.49$ & 13.8 & $25+0.71$ & 0.5 \\
\hline $\begin{array}{l}43300 \\
\text { E.faecalis }\end{array}$ & $9 \pm 0.71$ & $0.625 / 1.25$ & $8.5 \pm 0.57$ & 0.625 & $6.5 \pm 0.28$ & 13.8 & $26+1.41$ & 0.5 \\
\hline $\begin{array}{l}\text { ATCC } 29212 \\
\text { K.pneumoniae }\end{array}$ & $9 \pm 0.35$ & 1.25 & $9 \pm 0.28$ & 1.25 & $6.5 \pm 0.42$ & 13.8 & $20+0.71$ & 1 \\
\hline $\begin{array}{l}\text { ATCC } 4352 \\
\text { B.subtilis }\end{array}$ & $8 \pm 0.28$ & $1.25 / 2.5$ & $8 \pm 0.42$ & $1.25 / 2.5$ & $6.5 \pm 0.28$ & 6.9 & $22+2.12$ & 0.5 \\
\hline $\begin{array}{l}\text { ATCC } 6633 \\
\text { P.aeruginosa }\end{array}$ & $9 \pm 0.71$ & $0.312 / 2.5$ & $10 \pm 0.49$ & $0.312 / 2.5$ & $6.5 \pm 0.49$ & 13.8 & $32+0.71$ & 0.5 \\
\hline $\begin{array}{l}\text { ATCC } 27853 \\
\text { P.mirabilis }\end{array}$ & $7.5 \pm 0.71$ & $1.25 / 2.5$ & $7 \pm 0.35$ & $0.625 / 1.25$ & $6.5 \pm 0.35$ & 6.9 & $33+2.82$ & 0.25 \\
\hline ATCC 7002 & $7 \pm 0.28$ & $1.25 / 2.5$ & $7 \pm 0.42$ & $1.25 / 2.5$ & $6.5 \pm 0.28$ & 6.9 & $33+2.12$ & 0.13 \\
\hline
\end{tabular}

The essential oil of ST (having MIC/MBC values of $0.3 / 1.25 \mathrm{mg} / \mathrm{mL}$ ) showed better activity than the essential oil of SH (having MIC/MBC values of $0.6 / 1.25 \mathrm{mg} / \mathrm{mL}$ ) especially against $S$. aureus and both showed the same activity at $0.3 \mathrm{mg} / \mathrm{mL}$ against $B$. subtilis. Modest activities against MRSA at MIC 0.6 $\mathrm{mg} / \mathrm{mL}$ were observed by both EOs. In addition, SH showed also a weak activity against Gram negative bacteria; E. coli and, P. aeruginosa at MIC $0.6 \mathrm{mg} / \mathrm{mL}$. However, these activities were weak in comparison to the positive control Ciprofloxacin (MIC values between 0.13-1.0 $\mu \mathrm{g} / \mathrm{mL}$ ). Both, ST and SH essential oils did not show any activity against $K$. pneumoniae, E. faecalis and $P$. mirabilis.

The ST and SH indicated significant antimicrobial activity against E. coli, S. aureus, MRSA, E. faecalis and $B$. subtilis (between $8.5-10.0 \mathrm{~mm}$ inhibition zones) by disc diffusion. Between 7-8 mm inhibition zones were observed against $P$. aeruginosa, $P$. mirabilis and $K$. Pneumonia (Table 2). Similar to the MIC/MBC results, all of the above mentioned activities were modest in comparison to the positive control Ciprofloxacin (23-40 mm inhibition zones).

A good antimicrobial activity with several studies has been performed on the EOs of $S$. tomentosa against S. aureus, B. subtilis, B. cereus, E. coli and E. aerogones [17, 33, 34]. Our results with the antibacterial activity of EOs of SH and ST show close similarities to the both studies.

In this study was presented first time the composition and antibacterial activity of endemic varieties of Salvia sericeo-tomentosa. Further trials on more pathogenic microorganisms, animal tests, 
pharmacological and toxicological examinations are required as a potential bactericidal agent in the treatment of infectious diseases. However, because of the high sabinyl acetate amount of the both varieties should be avoided in pregnant women and the dose depended toxicity studies are necessary.

\section{Acknowledgments}

The present work was supported by the Scientific and Technological Research Council of Turkey. Project No. 114S734.

\section{References}

[1] M. Namiki (1990). Antioxidants/antimutagens in foods, Crit. Rev. Food Sci. Nutr. 29, 273-300.

[2] W. Mingfu, L. Jiangang, R. Meera, S. Yu, J.L.V. Edmond, H. Tzou-Chi and H. Chi-Tang (1998). Antioxidative phenolic compounds from Sage (Salvia officinalis), J. Agric. Food Chem. 46, 4869-4873.

[3] J. E. F. Reynolds (1996). Martindale the extra pharmacopeia (31st ed.). London: Royal Pharmaceutical Society of Great Britain.

[4] B. Tepe, E. Donmez, M. Unlu, F. Candan, D. Daferera, G. Vardar-Unlu, M. Polissiou and A. Sokmen (2004). Antimicrobial and antioxidative activities of the essential oils and methanol extracts of Salvia cryptantha (Montbret et Aucher exBenth.) and Salvia multicaulis (Vahl), Food Chem. 84, 519-525.

[5] F. Bakkali, S. Averbeck, D. Averbeck and M. Idaomar (2008). Biological effects of essential oils - A review, Food Chem. Toxicol. 46, 446-475.

[6] S. Burt (2004). Essential oils: their antibacterial properties and potential applications in foods-A review, Int. J. Food. Microbiol. 94, 223-253.

[7] J.B. Walker, K.J. Sytsma, J. Treutlein and M. Wink (2004). Salvia (Lamiaceae) is not monophyletic: Implications for the systematics, radiation, and ecological specializations of Salvia and tribe Mentheae, Am. J. Bot. 91, 1115-1125.

[8] G.P.P. Kamatou, N.P. Makunga, W.P.N. Ramogola and A.M. Viljoen (2008). South African Salvia species: A review of biological activities and phytochemistry, J. Ethnopharmacol. 119, 664-672.

[9] F. Celep, M. Dogan and A. Duran (2009). A new record for the Flora of Turkey: Salvia viscosa Jacq. (Labiatae), Turk. J. Bot. 33, 57-60.

[10] R. Hamidpour, S. Hamidpour, M. Hamidpour and N. Shahlari (2013). Global journal of medical research pharma, Drug Discovery, Toxicology Med. 13, 1-8.

[11] B. Sreedhar, T.V. Reddy, C.N. Raju and G.V.S. Reddy (2016). Design, synthesis, characterization and bioassay of novel carboxamide derivatives of celecoxib, Org.Commun. 9 (3), 54-64.

[12] N. Tan, B. Sen, M. Bilgin and E. Tan (2015). Antimicrobial activity of extracts from an endemic Salvia cilicica Boiss. and Kotschy, Afr. J. Microbiol. Res. 9, 130-134.

[13] M. Varalakshmi and C. Nagaraju (2016). Synthesis, spectral characterization and biological activity of N-4-(N2-(trifluoromethylphenyl))sulfamoyl amide derivatives, Org.Commun. 9 (3), 94-101.

[14] M.S. Abu-Darwish, C. Cabral, I.V. Ferreira, M.J. Goncalves, C. Cavaleiro, M.T. Cruz, T.H. Al-Bdour and L. Salgueiro (2013). Essential oil of common Sage (Salvia officinalis L.) from Jordan: Assessment of safety in mammalian cells and its antifungal and anti-inflammatory potential, BioMed Res. Int. 2013, 1-9.

[15] T. Aşkun, K.H.C. Başer, G. Tümen and M. Kürkçüoğlu (2010). Characterization of essential oils of some Salvia species and their antimycobacterial activities, Turk. J. Biol. 34, 89-95.

[16] S.D. Hatipoglu, N. Zorlu, T. Dirmenci, A.C. Goren, T. Ozturk and G. Topcu (2016). Determination of volatile organic compounds in fourty five Salvia Species by thermal desorption-GC-MS technique, Rec. Nat. Prod. 10, 659-700.

[17] L. Moss, M. Rouse, K. Wesens and M. Moss (2010). Differential effects of the aromas of Salvia species on memory and mood, Hum. Psychopharmacol. Clin. Exp. 25, 388-396.

[18] Z. Ulukanli, S. Karabörklü, M. Cenet, O. Sagdic, I. Ozturk and M. Balcilar (2013). Essential oil composition, insecticidal and antibacterial activities of Salvia tomentosa Miller, Med. Chem. Res. 22, 832-840.

[19] N. Gürsoy, B. Tepe and H.A. Akpulat (2011). Chemical composition and antioxidant activity of the essential oils of Salvia palaestina (Bentham) and S. ceratophylla (L.), Rec. Nat. Prod. 5, 281-289.

[20] G. Topçu and A.C. Gören (2007). Biological activity of diterpenoids isolated from Anatolian Lamiaceae Plants, Rec. Nat. Prod. 1, 1-16.

[21] A. Ulubelen, G. Topçu and C.B. Johansson (1997). Norditerpenoids and diterpenoids from Salvia multicaulis with antituberculosis activity, J. Nat. Prod. 60, 1275-1280.

[22] N. Tan, D. Satana, B. Sen, E. Tan, H. Bardakc1 Altan, B. Demirci and M. Uzun (2016). Antimycobacterial and antifungal activities of selected four Salvia Species, Rec. Nat. Prod. 10, 593-603.

[23] T. Özek, N. Tabanca, F. Demirci, D.E. Wedge and K.H.C. Baser (2010). Enantiomeric distribution of some linalool containing essential oils and their biological activities, Rec. Nat. Prod. 4, 180-192.

[24] G. Fournier, N. Pages and I. Cosperic (1993). Contribution to the study of Salvia lavandulifolia essential oil: potential toxicity attributable to sabinyl acetate, Planta Med.59, 96-97. 
[25] E. Şarer (1988). Chemical investigations of volatile oil of S. yosgadensis Freyn. Et Bornm., Ankara Ecz. Fak. Derg. 18, 38-43.

[26] F. Senatore, N. A. Arnold and F. Piozzi (2004). Chemical composition of the essential oil of Salvia multicaulis Vahl. var. simplicifolia Boiss. growing wild in Lebanon, J. Chromatogr. A 1052, 237-240.

[27] M. Kelen and B. Tepe (2008). Chemical composition, antioxidant and antimicrobial properties of the essential oils of three Salvia species from Turkish flora, Biores. Technol. 99, 4096-4104.

[28] A. Kahraman, F. Celep, M. Doğan and S. Bagherpour (2010). A taxonomic revision of Salvia euphratica sensu lato and its closely related species (sect. Hymenosphace, Lamiaceae) using multivariate analysis, Turk. J. Bot. 34, 261-276.

[29] K.H.C. Başer, M. Kürkçüoğlu and Z. Aytaç (1998). Composition of the essential oil of Salvia euphratica Montbret et Aucher ex Bentham var. euphratica from Turkey, Flavour Fragr. J. 13, 63-64.

[30] A. Koçak and E. Bağci (2011). Chemical composition of essential oil of local endemic Salvia kronenburgii Rech. fil. to Turkey, JEOBP. 14, 360-365.

[31] N. Pages, G. Fournier, C. Baduel, N. Tur and M. Rusnac (1999). Sabinyl acetate, the main component of Juniperus sabina l'Hérit. essential oil, is responsible for antiimplantation effect, Phytother. Res. 10, 438- 440.

[32] N. Pages, G. Fournier, V. Velut and C. Imbert (1992). Potential teratogenicity in mice of the essential oil of Salvia lavandulifolia Vahl. Study of a Fraction Rich in Sabinyl Acetate, Phytother. Res. 6, 80-83.

[33] M. Z. Haznedaroglu, N. U. Karabay and U. Zeybek (2001). Antibacterial activity of Salvia tomentosa essential oil, Fitoterapia 72, 829-831.

[34] B. Tepe, D. Daferera, A. Sokmen, M. Sokmen and M. Polissiou (2005). Antimicrobial and antioxidant activities of the essential oil and various extracts of Salvia tomentosa Miller (Lamiaceae), Food Chem. 90, 333 340 .

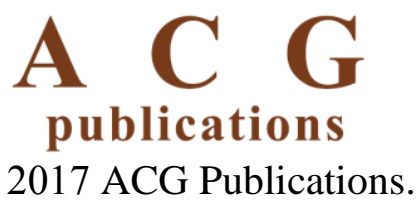

